\title{
Impact of scallop dredging on benthic megafauna: a comparison of damage levels in captured and non-captured organisms
}

\author{
S. R. Jenkins*, B. D. Beukers-Stewart, A. R. Brand \\ Port Erin Marine Laboratory (University of Liverpool), Port Erin, Isle of Man IM9 6JA, British Isles
}

\begin{abstract}
The impact of scallop dredging on benthic megafauna was assessed by direct observation of damage, both in the bycatch and in organisms encountering dredges but not captured. Damage was assessed using a simple 4point scale adapted for different taxonomic groups. Experimental dredging was undertaken on a scallop fishing ground in the north Irish Sea, off the Isle of Man. Divers were deployed immediately after dredges had passed, to record levels of damage to megafauna left in the dredge tracks. Mean damage levels, and the proportions of the 4 damage scores in the bycatch and on the seabed, were the same in most species. Some common species did show differences. The edible crab Cancer pagurus was more severely damaged when not captured, while the starfish Asterias rubens and whelk Neptunea antiqua received greater damage within the bycatch. Capture efficiency for the megafauna was low, ranging from 2 to $25 \%$ among species. The results indicate that the majority of damage to large benthic invertebrates during scallop dredging occurs unobserved on the seabed, rather than in the bycatch.
\end{abstract}

KEY WORDS: Dredging - Bycatch - Efficiency · Pecten · Epifauna

Resale or republication not permitted

without written consent of the publisher

The impact of demersal fishing gears on benthic communities has received increasing attention over the last decade (see Jones 1992, Dayton et al. 1995, Jennings \& Kaiser 1998 for reviews). Physical disturbance of the seabed and a consequent loss of habitat, in addition to the capture and mortality of non-target organisms, can cause significant changes to benthic community structure, both in the short (e.g. Bergman \& Hup 1992, Eleftheriou \& Robertson 1992, Kaiser et al. 1998), and long term (e.g. Greenstreet \& Hall 1996, Thrush et al. 1998, Hill et al. 1999). Mortality of large numbers of benthic organisms can have important

\footnotetext{
*E-mail: stu@liverpool.ac.uk
}

consequences at the population and community level through effects on trophic relationships and competitive interactions.

Of the demersal fishing gears currently used, toothed scallop dredges, which are designed to dig into the sediment, may be amongst the most damaging to benthic communities (Dayton et al. 1995, Collie et al. 2000). Experimental studies have revealed significant short-term changes in the abundance of many nontarget organisms after the passage of scallop dredges (Thrush et al. 1995, Currie \& Parry 1996, Kaiser et al. 1996). Removal of biota in the bycatch, which typically consists of the larger members of the epifauna (e.g. Hill et al. 1996) and some shallow burying infauna (Chapman et al. 1977, Hall-Spencer \& Moore 2000), may contribute significantly to changes in megafaunal density. However, high levels of mortality may also occur in organisms that encounter the dredge but are not captured. Observations by divers (Chapman et al. 1977, Eleftheriou \& Robertson 1992), remote video (Hall-Spencer et al. 1999) and from a submersible (Caddy 1973) have revealed a range of damaged epifaunal and shallow infaunal species left on the seabed after dredging. Such 'unobserved mortalities', resulting from gear encounters, are difficult to assess and have been largely ignored (Chopin \& Arimoto 1995).

We tested the hypothesis that dredge-induced damage is greater in bycatch organisms than in those left on the seabed by determining the level of damage in both groups of organisms in situ. Observations on dredge tracks were made by divers immediately after the passage of the fishing gear, and analysis of the catch was made on hauling. Simultaneous assessment of both bycatch and organisms left on the seabed was used to estimate capture efficiency for both target and non-target organisms. Data on capture efficiency and damage were used to predict the impact of scallop dredging on megafaunal communities. 
Methods. Dredging was undertaken by the RV 'Roagan' on the 'Bradda Inshore' scallop ground off the west coast of the Isle of Man. One gang of 4 'Newhaven' spring toothed dredges (see Dare et al. 1993 for description) was used on each side of the boat. Ten tows were carried out over the period July 12 to July 21, 2000 in water ranging in depth from 29 to $35 \mathrm{~m}$. All dredging took place within an area of $2.74 \mathrm{~km}^{2}$, which allowed clear separation of the dredge tracks. In accordance with common commercial practice, each tow lasted on average $45 \mathrm{~min}$ at a mean speed of 2.77 knots $\left(5.13 \mathrm{~km} \mathrm{~h}^{-1}\right)$. At the end of each tow the catch was sorted on deck and the abundance and damage score (see below) of all megafauna were recorded.

On each of the 10 tows the dive support vessel RV 'Sula' dropped 2 buoyed shot lines at timed intervals of 5 min immediately behind RV 'Roagan' as dredging was being carried out. In this way, 2 positions, separated by approximately $400 \mathrm{~m}$, were marked between the tracks made by the 2 gangs of dredges. At each shot line up to 2 pairs of divers were deployed, each pair locating and surveying a separate dredge track with a width of $3.5 \mathrm{~m}$. During the course of the survey, dredge tracks were marked in this way during both the first and second half of the tows.

A short interval after the shot lines had been positioned, divers located the dredge track, and surveyed the track for as far as possible given limitations of air and decompression requirements. Initially, divers entered the water $5 \mathrm{~min}$ after shotline deployment. However, the reduction in visibility caused by sediment disturbance during dredging made surveying difficult. Thus, the majority of dives took place 15 to 20 min after the passage of the dredge, when visibility had improved. The abundance and damage score of megafauna within the track, including the target organism Pecten maximus, were assessed. The sediment type and approximate depth of track furrows were also recorded. At the end of the survey a marker buoy was released. The distance between this marker and the shot line buoy was determined by the dive support vessels on the surface using a Global Positioning System, and gave an estimate of the distance surveyed by the divers. For each of the 10 tows, between 2 and 4 pairs of divers were deployed, making a total of 28 survey dives. The mean distance surveyed was $120 \mathrm{~m}$ (range: 25 to $283 \mathrm{~m}$ ) and a total of $2.99 \mathrm{~km}$ of track made by 1 gang of dredges $\left(10500 \mathrm{~m}^{2}\right)$ was covered by the divers.

Damage levels of megafauna were assessed both by divers and by scientists on board RV 'Roagan'. This was done in an identical manner using a simple 4-point scale, with the criteria used appropriate for each taxonomic group (Veale et al. 2001; Table 1). The mean damage index (MDI) for each species was calculated using the formula:

$$
\frac{\sum_{i=1}^{i=4} n_{i} i}{N}
$$

where $n_{i}=$ number of organisms of damage score $i$, and $N=$ total number of organisms.

A $t$-test was used to determine differences in the mean damage index between the bycatch and organisms left on the seabed. Data were first tested using an F-test to verify homogeneity of variances.

Results. Observations of dredge tracks showed that, within the experimental area covered $\left(2.74 \mathrm{~km}^{2}\right)$, sediment type varied from pure sand to a range of gravely sediments containing mud, sand, shell material, and stones, in varying proportions. Sediments varied over small spatial scales, with distinct changes apparent over 10 s of metres. The dredge tracks were not always distinct, even though dives took place only 15 to $20 \mathrm{~min}$ after dredging. The depth of furrows made by the dredge teeth varied from zero up to $5-8 \mathrm{~cm}$, with the majority only $1-2 \mathrm{~cm}$ deep. Tracks were more obvious, with deeper furrows, in coarse, loose sediment. A variety of dead and damaged species was observed within the dredge tracks (see below). In addition, 3 species were observed preying on dead or damaged individuals: the flatfish Limanda limanda, the dogfish Scyliorhinus canicula and the crab Cancer pagurus. These are all mobile species that could aggregate quickly on damaged organisms.

Damage levels (calculated as mean damage index) differed greatly among species (Table 2). Statistical comparison between damage levels in the bycatch and in organisms left on the seabed were carried out for

Table 1. Damage scores for megafauna (after Veale et al. 2001)

\begin{tabular}{|lllll|}
\hline & \multicolumn{1}{c}{1} & \multicolumn{1}{c}{2} & \multicolumn{1}{c|}{3} & \multicolumn{1}{c|}{4} \\
\hline Crabs & $\begin{array}{l}\text { In good } \\
\text { condition }\end{array}$ & $\begin{array}{l}\text { Legs missing/ } \\
\text { small carapace } \\
\text { cracks }\end{array}$ & $\begin{array}{l}\text { Major carapace } \\
\text { cracks }\end{array}$ & $\begin{array}{l}\text { Crushed/ } \\
\text { dead }\end{array}$ \\
Starfish & $\begin{array}{l}\text { In good } \\
\text { condition }\end{array}$ & Arms missing & $\begin{array}{l}\text { Worn and arms } \\
\text { missing/minor } \\
\text { disc damage }\end{array}$ & $\begin{array}{l}\text { Major disc } \\
\text { damage/ } \\
\text { dead }\end{array}$ \\
Urchins & $\begin{array}{l}\text { In good } \\
\text { condition }\end{array}$ & $<50 \%$ spine loss & minor cracks & $\begin{array}{l}\text { Crushed/ } \\
\text { dead }\end{array}$ \\
Whelks & $\begin{array}{l}\text { In good } \\
\text { condition }\end{array}$ & $\begin{array}{l}\text { Edge of shell } \\
\text { chipped }\end{array}$ & $\begin{array}{l}\text { Shell cracked or } \\
\text { punctured } \\
\text { Crushed/ } \\
\text { dead }\end{array}$ \\
Bivalves & $\begin{array}{l}\text { In good } \\
\text { condition }\end{array}$ & $\begin{array}{l}\text { Edge of shell } \\
\text { chipped }\end{array}$ & large crack & $\begin{array}{l}\text { Crushed/ } \\
\text { dead }\end{array}$ \\
\hline
\end{tabular}


Table 2. Mean damage index (MDI) of common megafaunal species found in bycatch, and left on the seabed in dredge tracks, following dredging using spring toothed scallop dredges (ns: not significant; ${ }^{*} p<0.05$ ). Species belong to the following taxonomic groups: ${ }^{1}$ Class Asteroidea, Phylum Echinodermata; ${ }^{2}$ Class Gastropoda, Phylum Mollusca; ${ }^{3}$ Class Malacostraca, Phylum Crustacea; ${ }^{4}$ Class Echinoidea, Phylum Echinodermata

\begin{tabular}{|lccc|}
\hline Species & Bycatch & Dredge track & $\begin{array}{c}\text { Bycatch vs } \\
\text { dredge track }\end{array}$ \\
\hline Porania pulvillus $^{1}$ & 1.0 & 1.0 & $\mathrm{~ns}$ \\
Crossaster papposus $^{1}$ & 1.1 & 1.1 & $\mathrm{~ns}$ \\
Asterias rubens $^{1}$ & 1.4 & 1.1 & ${ }^{*}$ \\
Astropecten irregularis $^{1}$ & 1.4 & 1.4 & $\mathrm{~ns}$ \\
Neptunea antiqua $^{2}$ & 1.7 & 1.2 & ${ }^{*}$ \\
Liocarcinus spp. $^{3}$ & 1.9 & 2.3 & $\mathrm{~ns}$ \\
Cancer pagurus $^{3}$ & 2.0 & 2.9 & ${ }^{*}$ \\
Echinus esculentus $^{4}$ & 2.2 & 2.1 & $\mathrm{~ns}$ \\
Luidia ciliaris $^{1}$ & 2.6 & 2.1 & $\mathrm{~ns}$ \\
\hline
\end{tabular}

each species using $t$-tests. Data were pooled over the 2 tows on each of the 5 days of the survey to give 5 replicate damage estimates. Three species showed significant differences between the bycatch and the seabed: Asterias rubens and Neptunea antiqua were more severely damaged in the bycatch $(\mathrm{df}=8, t=3.64$, $\mathrm{p}<0.01 ; \mathrm{df}=8, t=2.47, \mathrm{p}<0.05)$, whilst Cancer pagurus was more severely damaged in the dredge track $(\mathrm{df}=8, t=2.63, \mathrm{p}<0.05)$. No other significant differences could be detected.

The proportions of the 4 damage scores for each species are shown in Fig. 1. Comparison between the bycatch and those left on the seabed shows that for many species (Crossaster papposus, Astropecten irregularis, Porania pulvillus, Echinus esculentus, Pecten maximus) proportions with each damage score were very similar. For other species there were clear differences. For example, in both crab species, Cancer pagurus and Liocarcinus spp., the proportion of crushed or dead (score 4) animals left on the seabed was nearly twice as high as in the bycatch.

The efficiency of capture of megafaunal epibenthos by scallop dredges varied greatly from just over $2 \%$ for Astropecten irregularis and Neptunea antiqua, to $25 \%$ for the edible crab Cancer pagurus (Fig. 2). Capture of the target organism Pecten maximus, showed an efficiency of just under $19 \%$, similar to previous estimates for spring toothed dredges on sandy gravel sediments (Chapman et al. 1977, Dare et al. 1993). Of the scallops left in the dredge track only $15 \%$ were still recessed in the sediment, indicating that the majority of uncaptured scallops had been lifted from the sediment by the passage of the dredge.

Combining data from the seabed and bycatch allowed prediction of the level of damage suffered by

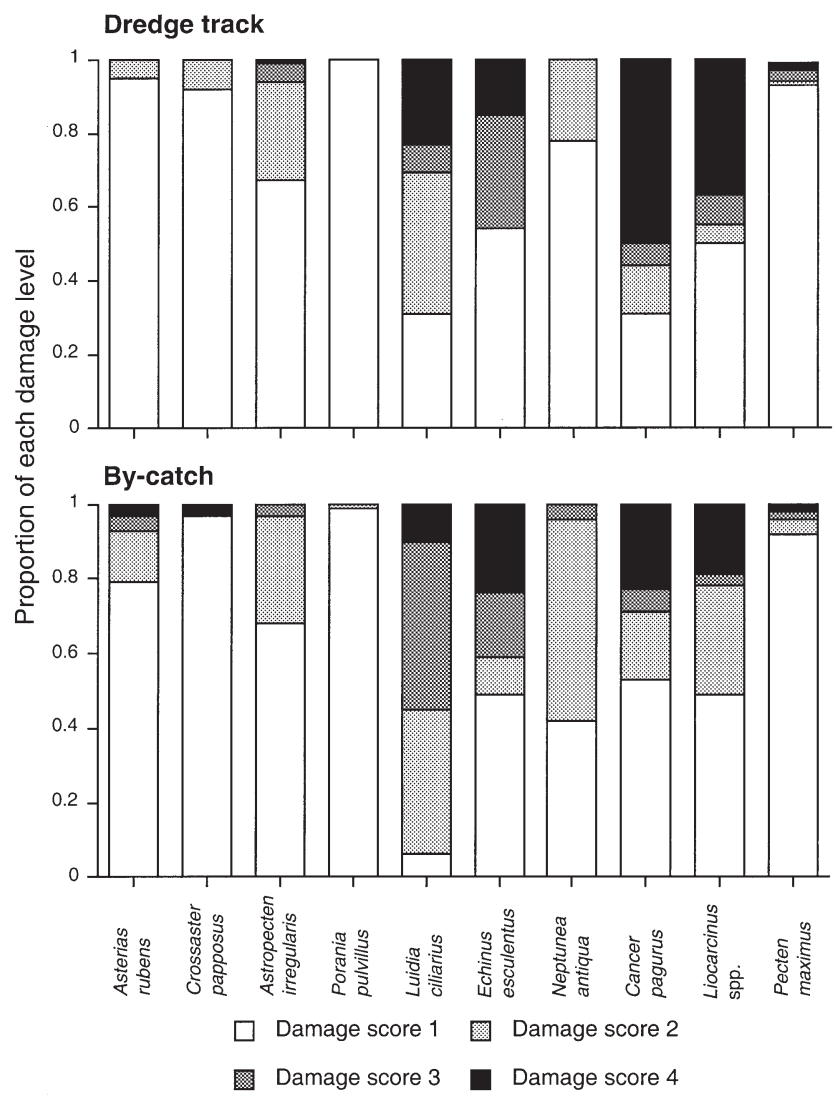

Fig. 1. Proportion of individuals of 10 megafaunal species found for each of 4 damage scores in the bycatch and left in the dredge track

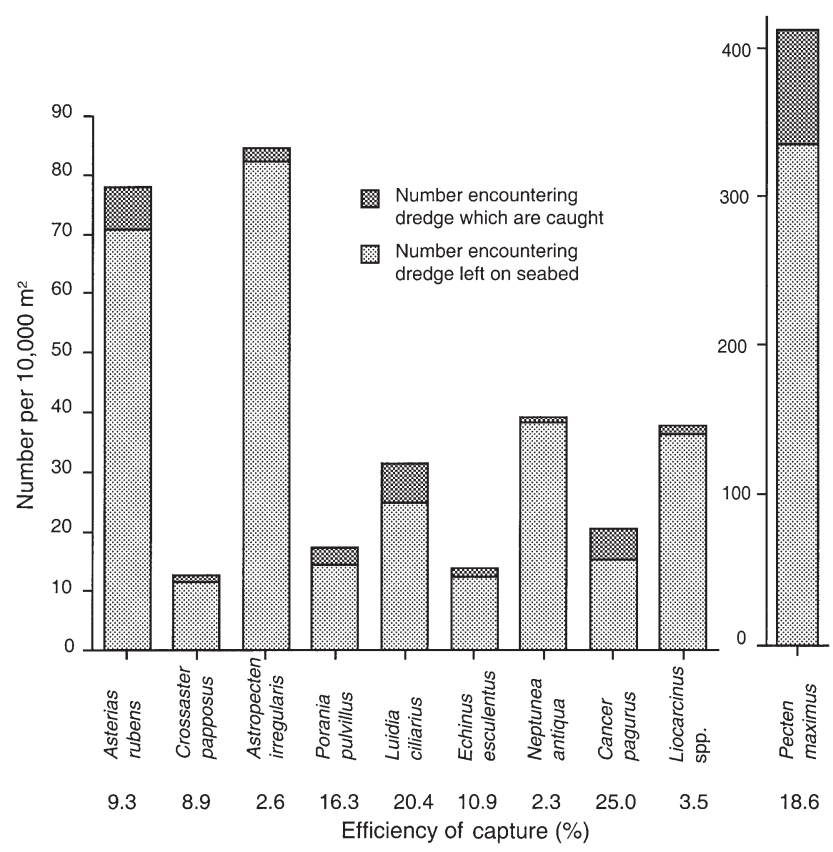

Fig. 2. Density (calculated as number per $10000 \mathrm{~m}^{2}$ of seabed) and efficiency of capture by spring toothed scallop dredges of 10 megafaunal species 
all organisms that encountered the dredge, whether caught or not (Table 3). This further illustrates that some species are little affected by dredging (e.g. Porania pulvillus, Asterias rubens), while in others over $40 \%$ are badly damaged (scores 3 and 4 ).

Discussion. The mean level of damage to a number of common megafaunal species showed surprisingly similar levels between captured organisms landed on deck (bycatch), and those encountering the dredge but left on the seabed. Where differences were apparent there was no consistency in the ranking of the 2 classes of fauna. This is the first study of demersal fishing gear to demonstrate equivalent levels of damage to benthic megafauna whether captured or not. We had hypothesised that damage would be greater in the bycatch, on the assumption that captured organisms would be subject to longer periods of mechanical disturbance whilst retained in the belly of the dredge. However, damage may also be caused by crushing as animals pass around or under the heavy gear or by the initial encounter with the tooth bar. Our results show that for one species at least (Cancer pagurus), fishing-induced damage may be higher in individuals not captured, suggesting that crushing by gear passing over an individual may be more harmful than being captured and retained in the dredge belly.

The implications of fishing-induced damage to the individual may be measured in terms of increased mortality, either directly (van Beek et al. 1990, Kaiser \& Spencer 1995, Hill et al. 1996), or indirectly, through the increased probability of predation (Caddy 1968) or disease (McLoughlin et al. 1991). Alternatively, physical damage may result in a reduction in levels of growth and/or reproductive output (Clapp \& Clark 1989). Previous work in the Irish Sea has shown a high probability of mortality in the short term (3 d) in benthic invertebrate species, with damage scores of 3 or more (Hill et al. 1996). High levels of mortality in cer-

Table 3. Predicted level of damage to megafauna in the path of spring toothed scallop dredges (bycatch and non-captured animals combined) as a percentage of individuals with each damage score. Damage scores as in Table 1

\begin{tabular}{|lrrrr|}
\hline \multirow{2}{*}{ Species } & \multicolumn{4}{c|}{ Damage score } \\
& 1 & \multicolumn{1}{c|}{2} & \multicolumn{1}{c|}{3} & \multicolumn{1}{c|}{4} \\
\hline Asterias rubens & 93.2 & 6.2 & 0.4 & 0.2 \\
Crossaster papposus & 92.1 & 7.6 & 0.0 & 0.3 \\
Astropecten irregularis & 67.5 & 26.8 & 4.6 & 1.1 \\
Porania pulvillus & 99.8 & 0.2 & 0.0 & 0.0 \\
Luidia ciliaris & 53.3 & 38.6 & 15.3 & 20.4 \\
Echinus esculentus & 53.3 & 1.1 & 29.3 & 16.4 \\
Neptunea antiqua & 76.7 & 23.2 & 0.1 & 0.0 \\
Cancer pagurus & 36.8 & 13.9 & 6.1 & 43.2 \\
Liocarcinus spp. & 50.0 & 6.1 & 7.7 & 36.3 \\
Pecten maximus & 93.0 & 1.8 & 2.9 & 2.3 \\
\hline
\end{tabular}

tain megafaunal species may result in radical changes in community structure (see Jennings \& Kaiser 1998 for review).

Spring toothed scallop dredges are relatively inefficient in capturing the target organism Pecten maximus, with estimates ranging from 6 to $41 \%$ of scallops over $90 \mathrm{~mm}$ in size depending on ground type (Dare et al. 1993). Our estimate of capture efficiency for nontarget organisms showed large variability among species but efficiency was generally low $(<25 \%)$. Thus, the majority of megafauna which encounter scallop dredges remain on the seafloor. Given that levels of damage to organisms left on the seabed were similar and in some cases higher than in the organisms captured, it is clear that the majority of damage and subsequent mortality of benthic megafauna takes place in the dredge tracks, and not in the discarded bycatch. Bergmann \& van Santbrink (2000), using remote sampling before and after fishing, made a similar conclusion regarding the impact of beam and otter trawling in the North Sea.

The development of gear designs to reduce the bycatch of commercial species has been based on the assumption that animals that escape suffer negligible mortality. Our study and others show that this is clearly not true (see Chopin \& Arimoto 1995 for review). While few attempts have been made to reduce the bycatch of benthic invertebrates, increasing emphasis on fishing effects at the ecosystem level may mean future fishing management decisions incorporate non-target species. In this case, the unobserved mortalities of organisms left on the seabed should be taken into account.

Acknowledgements. This study was supported by the EU project ECODREDGE (FAIR CT98-4465) and the Department of Agriculture Fisheries and Forestry of the Isle of Man Government. Many thanks to the boat crews of the RV 'Roagan', RV 'Sula' and 'Corallina' and to the numerous divers and shipboard scientists who took part in the surveys.

\section{LITERATURE CITED}

Bergman MJN, Hup M (1992) Direct effects of beam trawling on macrofauna in a sandy sediment in the southern North Sea. ICES J Mar Sci 49:5-11

Bergman M, van Santbrink J (2000) Fishing mortality of populations of megafauna in sandy sediments. In: Kaiser M, de Groot S (eds) Effects of fishing on non-target species and habitats. Blackwell Sciences, Oxford, p 49-68

Caddy JF (1968) Underwater observations on scallop (Placopecten magellanicus) behaviour and drag efficiency. J Fish Res Board Can 25:2123-2141

Caddy JF (1973) Underwater observations on the tracks of dredges and trawls and some effects of dredging on a scallop ground. J Fish Res Board Can 30:173-180

Chapman CJ, Mason J, Kinnear JAM (1977) Diving observations on the efficiency of dredges used in the Scottish fishery for the scallop, Pecten maximus (L.). Scottish Fish Res Rep 10 
Chopin FS, Arimoto T (1995) The condition of fish escaping from fishing gears - a review. Fish Res 21:315-327

Clapp D, Clark R Jr (1989) Hooking mortality of smallmouth bass caught on live minnows and artificial spinners. North Am J Fish Manage 9:81-85

Collie JS, Hall SJ, Kaiser MJ, Poiner IR (2000) A quantitative analysis of fishing impacts on shelf-sea benthos. J Anim Ecol 69:785-798

Currie DR, Parry GD (1996) Effects of scallop dredging on a softsediment community-a large-scale experimental study. Mar Ecol Prog Ser 134:131-150

Dare PJ, Key D, Darby CD, Connor PM (1993) The efficiency of spring-loaded dredges used in the western English Channel fishery for scallops, Pecten maximus (L.). ICES CM1993/B:15

Dayton PK, Thrush SF, Agardy TM, Hofman RJ (1995) Environmental effects of marine fishing. Aquat Conservation: Mar Freshw Ecosyst 5:205-232

Eleftheriou A, Robertson MR (1992) The effects of experimental scallop dredging on the fauna and physical environment of a shallow sandy community. Neth J Sea Res 30:289-299

Greenstreet SPR, Hall SJ (1996) Fishing and the ground-fish assemblage structure in the north-western North Sea: an analysis of long-term and spatial trends. J Anim Ecol 65:577-598

Hall-Spencer J, Moore P (2000) Impact of scallop dredging on maerl grounds. In: Kaiser M, de Groot S (eds) Effects of fishing on non-target species and habitats. Blackwell Science, Oxford, p 105-118

Hall-Spencer JM, Froglia C, Atkinson RJA, Moore PG (1999) The impact of Rapido trawling for scallops, Pecten jacobaeus (L.), on the benthos of the Gulf of Venice. ICES J Mar Sci 56:111-124

Hill AS, Brand AR, Wilson UAW, Veale LO, Hawkins SJ (1996) Estimation of by-catch composition and the numbers of by-catch animals killed annually on Manx scallop fishing grounds. In: Greenstreet SPR, Tasker ML (eds) Aquatic predators and their prey. Blackwell Science, Oxford, p 111-115

Editorial responsibility: Otto Kinne (Editor), Oldendorf/Luhe, Germany
Hill AS, Veale LO, Pennington D, Whyte SG, Brand AR, Hartnoll RG (1999) Changes in Irish Sea benthos: possible effects of forty years of dredging. Estuar Coast Shelf Sci 48:739-750

Jennings S, Kaiser MJ (1998) The effects of fishing on marine ecosystems. Adv Mar Biol 34:201-351

Jones JB (1992) Environmental impact of trawling on the seabed: a review. NZ J Mar Freshw Res 26:59-67

Kaiser MJ, Spencer BE (1995) Survival of by-catch from a beam trawl. Mar Ecol Prog Ser 126:31-38

Kaiser MJ, Hill AS, Ramsay K, Spencer BE, Brand AR, Veale LO, Prudden K, Rees EIS, Munday BW, Ball B, Hawkins SJ (1996) Benthic disturbance by fishing gear in the Irish Sea: a comparison of beam trawling and scallop dredging. Aquat Conserv 6:269-285

Kaiser MJ, Edwards DB, Armstrong PJ, Radford K, Lough NEL, Flatt RP, Jones HD (1998) Changes in megafaunal benthic communities in different habitats after trawling disturbance. ICES J Mar Sci 55:353-361

McLoughlin RJ, Young PC, Martin RB, Parslow J (1991) The Australian scallop dredge: estimates of catching efficiency and associated indirect fishing mortality. Fish Res 11:1-24

Thrush SF, Hewitt JE, Cummings VJ, Dayton PK (1995) The impact of habitat disturbance by scallop dredging on marine benthic communities: what can be predicted from the results of experiments? Mar Ecol Prog Ser 129:141-150

Thrush SF, Hewitt JE, Cummings VJ, Dayton PK, Cryer M, Turner SJ, Funnell GA, Budd RG, Milburn CJ, Wilkinson MR (1998) Disturbance of the marine benthic habitat by commercial fishing: impacts at the scale of the fishery. Ecol Appl 8:866-879

van Beek FA, van Leeuwen PI, Rijnsdorp AD (1990) On the survival of plaice and sole discards in the otter-trawl and beam-trawl fisheries in the North Sea. Neth J Sea Res 26:151-160

Veale LO, Hill AS, Hawkins SJ, Brand AR (2001) Distribution and damage to the by-catch assemblage of the northern Irish Sea scallop dredge fisheries. J Mar Biol Assoc UK 81:85-96

Submitted: November 20, 2000; Accepted: March 15, 2001 Proofs received from author(s): March 17, 2001 